\title{
Decontamination Testing of Radioactive-Contaminated Stainless Steel Coupons Using A Ce(IV) Solution
}
L. A. Bray
$R_{n}$ J. Elovich
M. R. Elmore
G. M. Richardson
K. I. Carson
L. D. Anderson

August 1992

Prepared for the U.S. Department of Energy under Contract DE-AC06-76RLO 1830

Pacific Northwest Laboratory Operated for the U.S. Department of Energy by Battelle Memorial Institute 


\title{
DISCLAIMER
}

This report was prepared as an account of work sponsored by an agency of the United States Government. Neither the United States Government nor any agency thereof, nor Battelle Memorial Institute, nor any of their employees, makes any warranty, expressed or implied, or assumes any legal liability or responsibillity for the accurac $y$, completeness, or usefulness of any information, apparatus, product, or process disclosed, or represents that its use would not infringe privately owned rights. Reference herei'a to any specific commercial product, process, or service by trade name, trademark, manufacturer, or otherwise does not necessarily constitule or imply its endorsement, recommendation, or favoring by the United States Government or any agency ihereof, or Battelle Memorial institute. The views and opinions of authors expressed herein do not necessarily state or reflect those of the United States Covernment or any agency thereof.

\author{
PACIFIC NORTHWEST LABORATORY \\ operated by \\ BATTELLE MEMORIAL INSTITUTE \\ for the \\ UNITED STATES DEPARTMENT OF ENERGY \\ under Contract DE-ACO6-76RLO 1830
}

Printed in the United States of America

Avallabie to DOE and DOE contractors from the

Office of Scientific and Techulical Information, P.O. Box 62, Oak Ridge, TN 37831;

prices available from (615) 576-8401. FTS 626-8401.

Available to the public from the National Technical Information Service,

U.S. Department of Commerce, 3285 Port Royal Rd., Springifiald, VA 22161. 
L. A. Bray

M. R. Elmore

K. J. Carson
R. J. Elovich

G. M. Richardson

L. D. Anderson

August 1992

Prepared for

the U.S. Department of Energy

under Contract DE-ACO6-76RLO 1830

Pacific Northwest Laboratory

Richland, Washington 99352 


\section{SUMMARY}

The current Hanford Waste Vitrification Plant (HWVP) reference process for canister decontamination describes an air-atomized frit/water slurry blaster developed for the Defense Waste Processing Facility (DWPF). Westinghouse Hanford Company (WHC) identified incentives to evaluate potential HWVP cost savings from adapting the $\mathrm{Ce}$ (IV)/ $/ \mathrm{NO}_{3}$ canister decontamination approach being developed for the West Valley Demonstration Project (WVDP) at West Valley, New York. Development studies were recommended by WHC to address issues related to further assessment of the adaptation of the $\mathrm{Ce}(\mathrm{IV}) / \mathrm{HNO}_{3}$ decontamination system to HWVP, and to resolve a number of technical uncertainties.

Laboratory studies at the Pacific Northwest Laboratory (PNL) were performed to provide further data to support the selection of an effective flowsheet for the $\mathrm{Ce}$ (IV)/ $/ \mathrm{HNO}_{3}$ decontamination of HWVP stainless steel (SS) vitrification canisters. The results reconfirmed the predictability of this unique chemical milling and decontamination process. The results were equivalent to those found in Bray's initial WVDP study (1988). A thin layer (2.5 to $5 \mu \mathrm{m})$ of oxidized SS metal surface was effectively removed from 304L coupons by chemical milling with a $0.5 \mathrm{M}$ to $1 \underline{\mathrm{M} \mathrm{HNO}} \mathrm{H}_{3}$ solution containing -1.4 to 2.7 moles of $\mathrm{Ce}$ (IV) per square meter of surface area to provide adequate radioactive surface decontamination. Nitric acid treatment alone was not sufficient to provide adequate decontamination in either study. A chemical milling contact time of $6 \mathrm{~h}$ at $65^{\circ} \mathrm{C}$ was adequate to decontaminate the coupons to levels below the Waste Acceptance Preliminary Specifications (WAPS) (DOE 1990) of $<2,200$ disintegrations per minute (dpm) gamma of smearable contamination per $100 \mathrm{~cm}^{2}$ of surface.

The decontamination process developed in the laboratory will be scaled up by a factor of 5,000:1 and tested in FY 1992 by the WVDP at West Valley using uncontaminated full-scale glass-filled canisters. An engineering uncertainty remains to be resolved concerning the removal of a layer of loosely held oxide, some of which may remain on the SS surface after removal of the 
canister from the decontamination solution. In this laboratory study, lowpressure water from a standard laboratory wash bottle was used to rinse the surfaces of the test coupons. WVDP will test a series of jet nozzles to thoroughly wash the decontaminated canister. Data obtained from the full-scale WVDP test program will include confirmation of the required soak time, temperature, $\mathrm{Ce}(\mathrm{IV}) / \mathrm{HNO}_{3}$ concentration, and design of the decontamination equipment. These results will be monitored and evaluated for applicability to HWVP canister decontamination. Ultrasonic agitation has been a suggested alternative or addition to spray nozzles for rinsing but has not been selected for the initial series of full-scale tests. 


\section{CONTENTS}

SUMMARY

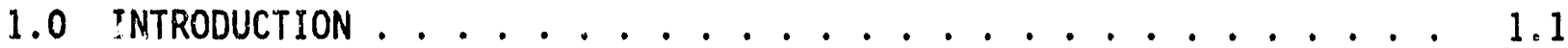

2.0 CONCLUSIONS AND RECOMMENDATIONS . . . . . . . . . . . 2.1

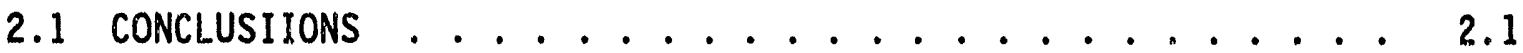

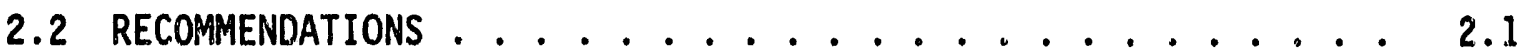

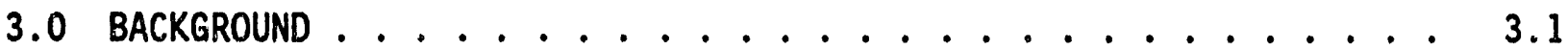

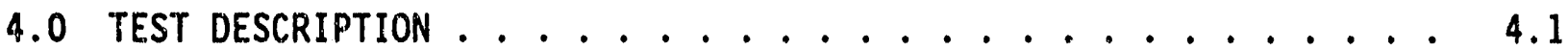

4.1 TEST PHASES . . . . . . . . . . . . . . . . 4.1

4.1.1 Phase 1: Preparation of SS Coupons ........ 4.1

4.1.2 Phase 2: Preparation of ${ }^{137}$ Cs Contaminated SS Coupons................ 4.1

4.1.3 Phase 3: Oxidation of Contaminated Coupons . . . . 4.1

4.1.4 Phase 4: Decontamination of Contaminated Coupons............. 4.2

4.1.5 Phase 5: Smear Tests of Decontaminated Coupons........... 4.2

4.2 SMEAR TESTING ..................... 4.3

5.0 RESULTS AND DISCUSSION . . . . . . . . . . . . . . 5.1

5.1 EFFECT OF Ce(IV) CONCENTRATION . . . . . . . . . 5.2

5.2 EFFECT OF TEMPERATURE ................. . . . 5.2

5.3 EFFECT OF ACID CONCENTRATION . . . . . . . . . . 5.4

5.4 EFFECT DF CONTACT TIME . . . . . . . . . . . . 5.5

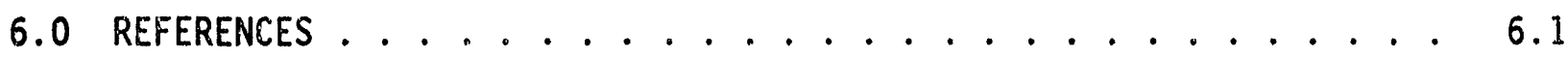

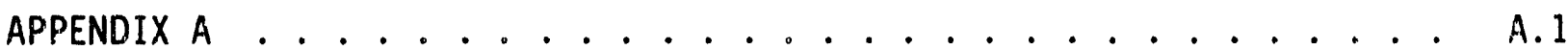




\section{FIGURES}

3.1 Effect of Cerium Concentration on the Dissolution of Stainless Steel, $65^{\circ} \mathrm{C}$.................. 3.2

4.1 Smear Tool for Ce(IV) Decontamination Testing . . . . . . . 4.4

5.1 Smear count $\left(\mathrm{dpm} / 100 \mathrm{~cm}^{2}\right)$ and Penetration $(\mu \mathrm{m})$ as a Function of the Ce(IV) Concentration .............. 5.3

5.2 Smear Count $\left(\mathrm{dpm} / 100 \mathrm{~cm}^{2}\right)$ and Penetration $(\mu \mathrm{m})$ as a Function

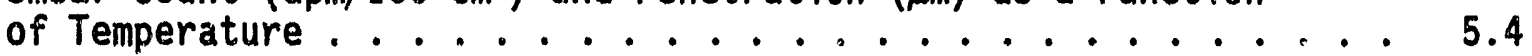

5.3 Smear Count $\left(\mathrm{dpm} / 100 \mathrm{~cm}^{2}\right)$ and Penetration $(\mu \mathrm{m})$ as a Function of Contact Time .................. . . 5.6

5.4 Calculated Penetration $(\mu \mathrm{m})$ as a Function of Contact Time . . . 5.7

\section{TABLES}

$5.1 \mathrm{Ce}$ (IV) Concentration . . . . . . . . . . . . 5.3

5.2 Temperature ...................... 5.4

5.3 Acid Corcentration .................. 5.5

5.4 Contact rime ...................... 5.6

A.1 Coupon Weight Values Before and After Decontamination . . . . A.1

A.2 Ce(IV) Decontamination Test Conditions . . . . . . . . . A.2

A.3. Decontamination observations . . . . . . . . . . A.3

A.4 Decontamination Smear Results . . . . . . . . . . . A.4 


\subsection{INTRODUCTION}

The Hanford Waste Vitrification Plant (HWVP) is being designed to provide a vitrification facility to immobilize Hanford high-level waste (HLW) into a borosilicate glass matrix. The HLW will be pretreated and transferred to the vitrification facility as a feed slurry. In the HWVP, the waste is concentrated, chemically adjusted to create melter feed, and then converted to glass. The glass product will be sealed in stainless steel (SS) canisters, which are then decontaminated to remove smearable contamination and stored on-site until shipped to a federal repository. During the filling process and canister-handling operations, the outer surfaces of the canisters will become contaminated.

The current HWVP reference process for canister decontamination uses an air-atomized frit/water slurry blaster designed for the Savannah River Defense Waste Processing Facility (DWPF). Several other methods of canister decontamination have been investigated, including electropolishing, abrasive slurry blasting, high-pressure water washing, ultrasonic cleaning, and more recently the $\mathrm{Ce}(\mathrm{IV}) / \mathrm{HNO}_{3}$ chemical milling process (Bray 1988). An earlier evaluation by Westinghouse Hanford Company (WHC) identified incentives to evaluate potential HWVP cost savings from adapting the $\mathrm{Ce}(\mathrm{IV}) / \mathrm{HNO}_{3}$ canister decontamination approach (Bray 1988; Bray and Seay 1988) being developed for the West Valley Demonstration Project (WVDP) at West Valley, New York. Development studies were recommended by WHC to address issues related to further assessment of the adaptation of the $\mathrm{Ce}$ (IV)/ $/ \mathrm{HNO}_{3}$ decontamination system to HWVP, and to resolve a number of technical uncertainties.

The primary objective of this test was to determine the adequacy of the $\mathrm{Ce}(\mathrm{IV}) / \mathrm{HNO}_{3}$ decontamination process to remove smearable radioactivity $\left({ }^{137} \mathrm{Cs}\right.$ ) from radioactive-contaminated 304L SS coupons that have been fully oxidized by a simulated canister-filling heat treatment cycle. 


\subsection{CONCLUSIONS AND RECOMMENDATIONS}

\subsection{CONCLUSIONS}

- Results of these tests corroborated results of earlier similar tests. As discussed elsewhere in this report, earlier work comprised testing with oxidized but uncontaminated coupons and testing with contaminated but unoxidized coupons. The purpose of these latter tests was to determine if there might be any different response with coupons that had been contaminated and then oxidized to simulate canister filling with molten glass. The number of individual tests was limited, but no significant difference was noted between the results of these and earlier tests.

- A concentration of 1.4 moles to 2.7 moles of Ce(IV) per square meter of coupon surface area was adequate to decontaminate the coupons to below the Waste Acceptance Prel iminary Specifications (WAPS) limits of $2200 \mathrm{dpm}$ gamma/100 $\mathrm{cm}^{2}$ of smearable contamination (DOE 1990). This concentration of $\mathrm{Ce}$ (IV) was adequate when used in conjunction with a soak time of $6 \mathrm{~h}$, a soak temperature of $65^{\circ} \mathrm{C}$, and in a solution of $0.5 \mathrm{M}$ to $1.0 \mathrm{M} \mathrm{HNO}_{3}$.

- Nitric acid alone at $0.5 \mathrm{M}$ was insufficient for decontaminating the coupons.

- With a solution of $0.5 \mathrm{M} \mathrm{HNO}_{3}$ and $0.02 \mathrm{M} \mathrm{Ce}$ (IV) at $90^{\circ} \mathrm{C}$, a white precipitate believed to be an insoluble cerium salt was observed, and duplicate coupon results were inconsistent. A solubility problem with the Ce(IV) may exist at this high cerium concentration and temperature.

\subsection{RECOMMENDATIONS}

- Closely monitor full-scale testing to be conducted at WVDP. A need for additional engineering tests may be identified based on these results.

- Low-pressure water rinsing of certain coupons after Ce(IV) decontamination in the laboratory tests appeared inadequate to fully remove loosely held oxide film from the coupons. Although test results do not indicate a direct correlation of remaining smearable contamination and remaining loose oxide, further investigation of more energetic rinsing techniques after completion of the engineering tests is recommended.

- A better understanding of cerium solubility in nitric acid solutions is needed. Further investigation of the suspected retrograde solubility at higher temperatures is recommended to provide a more detailed understanding of the process. 


\subsection{BACKGROUND}

The WVDP selected the $\mathrm{Ce}$ (IV) canister decontamination process based on data obtained from Pacific Northwest Laboratory (PNL) ${ }^{\text {(a) }} 1$ laboratory-scale testing. The decontamination process has been tested on SS coupons hung on the outside of canisters and contaminated during actual HLW processing that involved the PNL Radioactive Liquid-Fed Ceramic Melter (RLFCM). Data were obtained during canister production for the Federal Republic of Germany (FRG) during FY 1987 (Thomas and Bray 1987). ${ }^{\text {(b) }}$ The surfaces of the tested SS coupons were not oxidized during the FRG test. Therefore, the decontamination process had not been tested for decontamination of radionuclides (i.e., ${ }^{137} \mathrm{Cs}$ ) from the surface of SS that had undergone the canister heating oxidation cycle. However, fully-oxidized coupons without radioactive contamination and radioactively contaminated coupons that have not been fully oxidized have been successfuily decontaminated.

To summarize Bray's previous (1988) tests, a thin layer (1.5 to $3 \mu \mathrm{m}$ ) of metal was effectively removed from the surface of 304L SS coupons by chemical milling with a $0.5 \mathrm{M} \mathrm{HNO}_{3}$ solution containing $~ 0.65$ to 1.4 moles of $\mathrm{Ce}$ (IV) per square meter of surface area ( 0.06 to 0.13 moles of $\left.\mathrm{Ce}(\mathrm{IV}) / \mathrm{ft}^{2}\right)$. For contaminated (but unoxidized) coupons, it was necessary to remove only $\sim 2$ to $3 \mu \mathrm{m}$ (about $0.1 \mathrm{mil}$ ) of the SS surface to provide adequate decontamination. Nitric acid treatment alone was insufficient in both cases. Based on the information in Bray (1988), chemical milling contact time was inversely proportional to the temperature. Contact times from 3 to $6 \mathrm{~h}$ at $65^{\circ} \mathrm{C}$ were adequate to decontaminate the FRG/RLFCM coupons to levels below the WAPS (see Figure 3.1). Preliminary examination of coupon photomicrographs using a scanning electron

(a) Pacific Northwest Laboratory is operated by Battelle Memorial Institute for the U.S. Department of Fnergy under Contract DE-AC06-76RLO 1830.

(b) Thomas, N. M., and L. A. Bray. 1987. Summary of RLFCM Canister Contamination Testing. WVST 87-263B, prepared for West Valley Nuclear Services Co., Inc., West Valley, New York. 


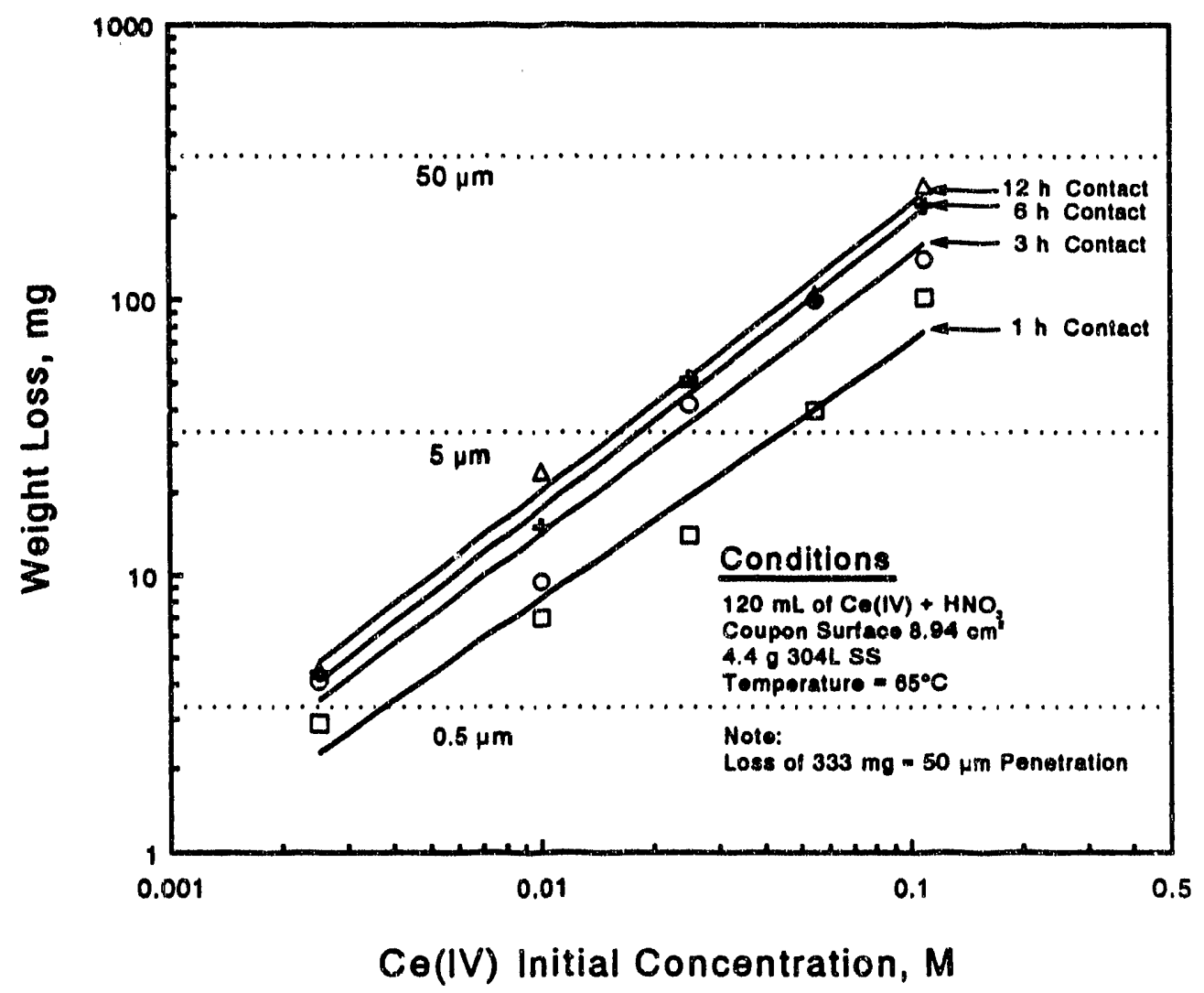

FIGURE 3.1. Effect of Cerium Concentration on the Dissolution of Stainless Steel, $65^{\circ} \mathrm{C}$ (Bray 1988)

microscope (SEM) showed that the surface dissolution was essentially uniform with minimal intergranular attack at $C e(I V)$ milling, or surface penetration, of less than $\sim 6 \mu \mathrm{m}$ (Bray 1988).

Additional work conducted by PNL for WVDP determined there was no impact on the canister label and welds (Westerman 1991), (a) and that even extensive metal removal (four-fold above that required) by the $\mathrm{Ce}$ (IV) decontamination method had no stress corrosion cracking-inducing effect on the canister

(a) Westerman, R. E. 1991. Legibility of Canister Weld Bead Labels Following Simulated Decontamination Treatments. WVSP 91-047, prepared for West Valley Nuclear Services Co., Inc., by the Pacific Northwest Laboratory, Richland, Washington. 
material tested (Pitman and Westerman 1990; (a) Westerman 1991). (b) Microscopic analysis of test coupons that had undergone "extensive" metal removal up to $11 \mu \mathrm{m}$ ( $0.4 \mathrm{mil})$ or surface penetration showed some preferential attack at grain boundaries, as expected. However, the attack appeared as blunt grooves at the grain boundaries, rather than deep, narrow cracks into the metal structure that are typically associated with stress corrosion cracking.

During FY 1992 the WVDP plans to perform $\mathrm{Ce}(\mathrm{IV}) / \mathrm{HNO}_{3}$ decontamination tests on full-size glass-filled canisters that are not radioactively contaminated. Data obtained from these tests will include confirmation of required soak time, temperature, $\mathrm{Ce}(\mathrm{IV}) / \mathrm{HNO}_{3}$ concentrations, and will aid in the design of the decontamination equipment. These tests will be monitored, and results will be evaluated for applicability to HWVF canister decontamination.

(a) Pitman, S. G., and R. E. Westerman. 1990. Evaluation of the Potential Susceptibility of AISI Type 304L Stainless Steel Waste Canisters to Stress Corrosion Cracking (SSC) from HNO ${ }_{3}$-Ce(IV) Decontamination - An Interpretive Literature Survey. WVSP $90-034$, prepared for West Val7ey Nuclear Services Co., Inc., by the Pacific Northwest Laboratory, Richland, Washington.

(b) Westerman, R. E. 1991. An Investigation of the Potential for a $\mathrm{HNO}_{3}=$ Cerium(IV) Decontamination Treatment to Induce Stress-Corrosion Cracking in Canister Materials. WVSP 91-042, prepared for West Valley Nuclear Services Co., Inc., by the Pacific Northwest Laboratory, Richland, Washington. 


\subsection{IEST DESCRIPIION}

\subsection{IEST PHASES}

This section describes the steps required to test fully-oxidized coupons contaminated with radioactive ${ }^{137} \mathrm{Cs}$. The experimental work was completed in five phases. The laboratory procedure for each testing phase is described below.

\subsubsection{Phase 1: Preparation of SS Coupons}

Stainless steel coupons measuring 1 in. $\times 0.6$ in. $\times 0.06$ in. thick ( $-9-\mathrm{cm}^{2}$ surface area) were cut from a single sheet of $304 \mathrm{~L}$ stainless steel. The 304L was procured with a standard mill finish, but otherwise the surface was free of oxide. The following information was obtained for each coupcn:

Certification No. of SS and Heat No.

Size: 1 in. $\times 0.6 \mathrm{in.} \times 0.06 \mathrm{in}$. thick with $0.12-\mathrm{in}$. hoie for hanging Note: The dimensions of ten randomily selected coupons were measured with micrometers. The average dimensions from these measurements were then used to determine a surface area $\left(8.806 \mathrm{~cm}^{2}\right)$, which was used for latar calculations.

Weight: $-4.5 \mathrm{~g}$ using a five-place balance

Marking: Each sample was marked with an identification number.

Before use, each coupon was washed with alcohol to remove cutting ofl.

\subsubsection{Phase 2: Preparation of ${ }^{137} \mathrm{Cs}$ Contaminated SS Coupons}

The coupons were contaminated with radioactive cesium chioride. This was accomplished by soaking each coupon for $24 \mathrm{~h}$ in $10 \mathrm{~mL}$ of distilled water containing ${ }^{137} \mathrm{Cs}$, followed by air drying. The ${ }^{137} \mathrm{Cs}$ solution was prepared by diluting a stock solution containing $9.68 \mathrm{mCi} / \mathrm{mL}{ }^{1.37} \mathrm{Cs}$ to a "working solution" containing $0.002 \mathrm{mct} / \mathrm{mL} .{ }^{137} \mathrm{Cs}$. A separate bottle containing $10 \mathrm{~mL}$ of this working solution was prepared for each coupon.

\subsubsection{Phase 3: Oxidation of Contaminated Cerupons}

The radioactive contaminated coupons were heat treated in a furnace at $600 . \mathrm{C}$ for $16 \mathrm{~h}$, in an tir atmosphere. This procedure was first used by 
W. N. Rankin (1982) to produce an oxide layer on SS similar to glass-filled canister surfaces. The heat-treated coupons were then cooled, reweighed, and counted to determine their oxidized weight and residual radioactivity (Appendix, Table A.1 and A.4). During surface oxidation, the coupons were suspended in the furnace on SS wires.

\subsubsection{Phase 4: Decontamination of Contaminated Coupons}

Twenty-four ${ }^{137} \mathrm{Cs}$ contaminated and heat-treated $\left(600^{\circ} \mathrm{C}\right.$ for $\left.16 \mathrm{~h}\right)$ coupons were each decontaminated using $120 \mathrm{~mL}$ of $\mathrm{Ce}(\mathrm{IV}) / \mathrm{HNO}_{3}$ test solution $\left(136 \mathrm{~L} / \mathrm{m}^{2}\right)$. One additional coupon was tested in $0.5 \mathrm{M} \mathrm{HNO}_{3}$ with no cerium. The coupons were tested under 12 conditions by varying the $\mathrm{Ce}(\mathrm{IV}) / \mathrm{HNO}_{3}$ concentration $\left(0.005 \mathrm{M}\right.$ to $0.02 \mathrm{MCe}$ (IV)/0.2 $\mathrm{M}$ to $\left.1 \mathrm{M} \mathrm{HNO} \mathrm{H}_{3}\right)$, the contact time ( 3 to $\left.12 \mathrm{~h}\right)$, and temperatur: $\left(25^{\circ}\right.$ to $90^{\circ} \mathrm{C}$ ), (Appendix, Table A.2). The Ce(IV) solutions were prepared by diluting from a concentrated $\mathrm{Ce} / \mathrm{HNO}_{3}$ stock solution. Prior to testing, the stock solution was oxidized in an electrochemical cell to ensure complete oxidation of cerium isn to $\mathrm{Ce}$ (IV).

Using Teflon pipe tape, the coupons were each suspended in $120 \mathrm{~mL}$ of decontamination solution contained in $250 \mathrm{ml}$. glass bottles with screw caps. The bottles were $p l a c e d$ in a temperature controlled water-bath shaker-table to maintain the assigned temperature. The coupons were removed from the solution and rinsed thoroughly with distilled water from a laboratory wash bottle. The washed coupons were then allowed to air dry for $24 \mathrm{~h}$. The loss in coupon metal and oxide weight was determined using a five-place analytical balance (see Table A.1). The loss of surface radioactive contamination was determined by gamma counting the coupon surface be ore and after decontamination. Each face of each coupon was then smear tested to determine the decontamination efficiency as a function of test conditions.

\subsubsection{Phase 5: Smear Tests of Decontaminated Coupons}

Smear tests of the decontaminated SS coupons were performed by wiping both sides of the coupon with circular $(4.5 \mathrm{~cm}$ dia.) adhesive-backed paper swabs (radiation monttoring technical smear pads). (a) The swabs were then

(a) Radiation Specialty Products, Inc., Dothan, Alabama 36302. 
gamma counted to determine the decontamination efficiency as a function of the test conditions, as compared to WAPS acceptance criteria $(<2,200 \mathrm{dpm}$ gamma/ $100 \mathrm{~cm}^{2}$ of surface).

\subsection{SMEAR TESTING}

In practice, smear testing is not a well-defined procedure. The purpose of smearing most objects is to determine whether or not any removable radioactive contamination exists on its surface. Because the object is typically wiped with a hand-held smear swab, the pressure applied and the area smeared are not precisely known. In the HWVP canister decontamination process, however, smear testing of decontaminated glass-filled canisters will be performed remotely by mechanical means. The variables will therefore be better defined and more consistent than is usually possible. To determine the conformance of test specimens to the WAPS, a hot-cell mechanical process was approximated as closely as possible b.l using a specially designed smear tool in a predetermined procedure. The specific technique to be used for HWVP canister smear testing is yet unknown, but for this test was assumed to be similar to that anticipated for the DWPF canister smear testing (i.e., smearing a known area of the canister surface with a smear pad applied at a known and constant pressure).

This smear tool consisted of a hard rubber disc attached to the end of a spring (Figure 4.1). The spring was housed in a tube long enough to permit compression of the spring and allow the smear swab to wipe the coupon's surface with $2.03 \mathrm{lbs} / \mathrm{in}^{2(\mathrm{a})}$ of force. The diameter of the rubber disc was sized to fit an adhesive smear swab.

The smear tool used two plates, one upper and one lower. The upper plate was the same thickness as the coupon, and had a rectangular hole cut through it just large enough to fit the coupon inside. The second plate was solid (no hole) and fit beneath the upper plate during the smear test. The smear test was performed as follows:

(a) Information provided by Savannah River site. 


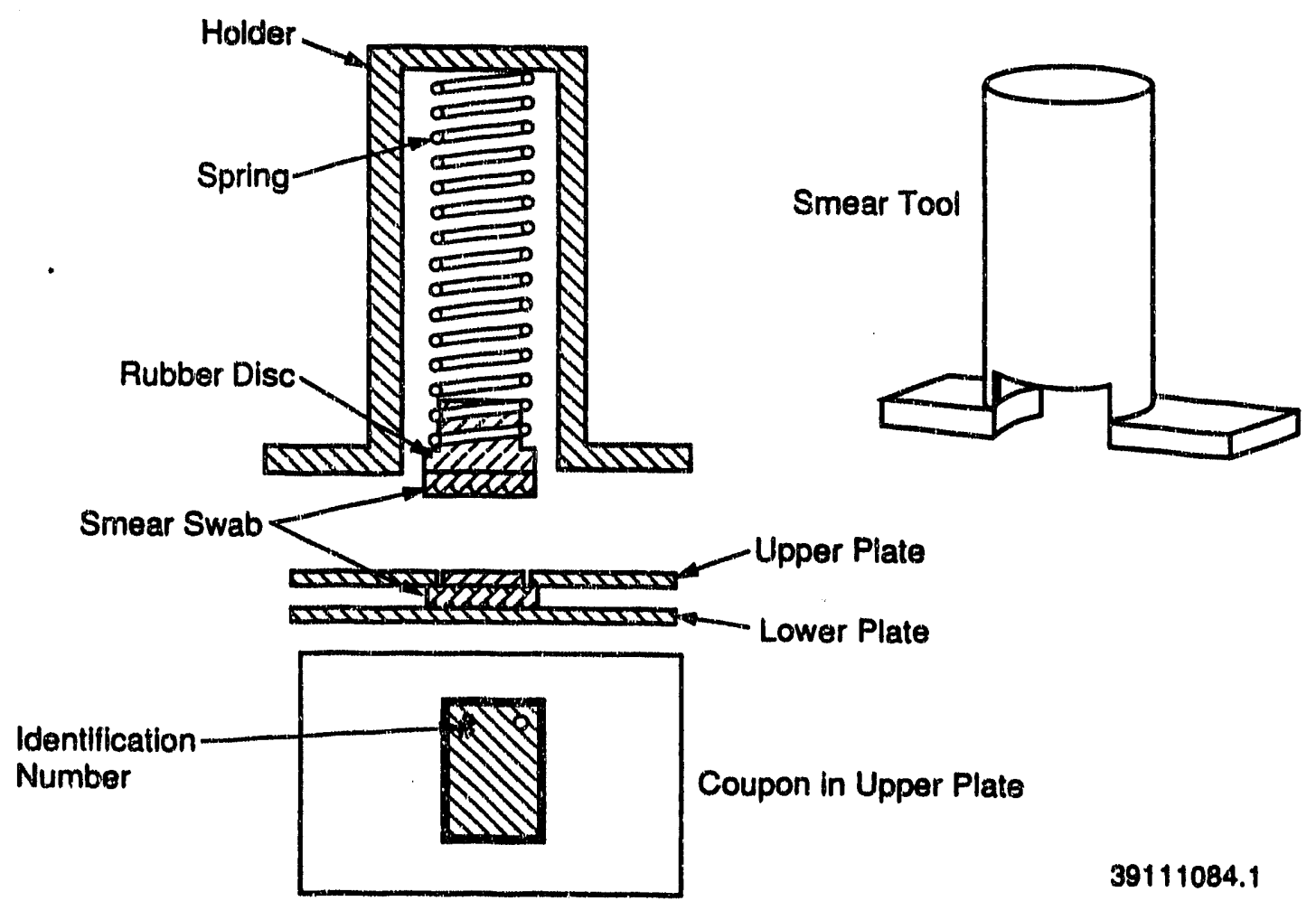

FIGURE 4.1. Smear Tool for Ce(IV) Decontamination Testing

1. One smear swab was adhered face-up to the center of the lower (solid) plate. The upper plate (with the rectangular hole) was placed directly above the lower plate, allowing the smear swab to be exposed through the rectangular hole. The decontaminated coupon was then placed in the hole, so that its identification number faced up. A second adhesive smear swab was attached to the rubber disc on the smear toot.

2. The smear tool was then held vertically and placed entirely to one side of the coupon. Next, the smear tool was pressed down until the housing was in contact with the upper plate, and the spring and disc were compressed within the housing. While the spring was compressed, the tool was drawn across the plate (with coupon) in a straight line until the smear swab was completely on the opposite side of the coupon.

3. The used smear swab was removed from the disc and placed in a plastic snap-lid sample vial. The coupon was then picked up with tongs and turned over to expose the back face in the slotted plate. A clean smear swab was then attached to the smear tool.

4. Step (2) was repeated to smear the second side of the coupon. 
5. The smear swab used in step (4) was removed from the rubber disc and placed on top of the first smear swab (step 3 ) in the plastic. snap-lid sample vial. The smear swab underneath the top plate was also removed and added to the snap-lid sample vial. All three smear pads were stored together in the sealed container for gamna counting.

6. Both plates and the smear tool were decontaminated with alcohol and water and surveyed before reuse.

7. A counting standard was prepared by absorbing and drying a known ${ }^{137} \mathrm{Cs}$ solution on a smear swab and placing the swab in a plastic snap-lid sample vial. The prepared standard was counted with the samples to correct the unknown sample values for vial geometry. 


\subsection{RESULTS AND OISCUSSION}

A test program was completed to provide further data to support the selection of an effective flowsheet for the decontamination of HWVP vitrification canisters. The results reconfirmed the predictability of this unique chemical milling and decontamination process. For contaminated (but unoxidized) coupons (Bray 1988), it was necessary to remove only $\sim 2$ to $3 \mu \mathrm{m}$ (about $0.1 \mathrm{mi1}$ ) of the SS surface to provide adequate decontamination. For contaminated oxidized coupons in this study, removal of 2.5 to $5 \mu \mathrm{m}$ of the SS surface provided adequate decontamination. Nitric acid treatment alone was insufficient to provide adequate decontamination in either study. A chemical milling contact time of $6 \mathrm{~h}$ at $65^{\circ} \mathrm{C}$, was adequate to decontaminate the coupons below the Waste Acceptance Preliminary Specifications (WAPS, DOE 1990).

Actual radioactive-contaminated SS canisters or coupon samples, fully oxidized by a canister-filling heat treatment cycle, were unavailable for this study. As out 7 ined in Section 4.0, test coupons were fabricated, contaminated with ${ }^{137} \mathrm{Cs}$, and heat-treated at $600^{\circ} \mathrm{C}$ for $16 \mathrm{~h}$ in air to simulate the surface of HWVP vitrification canisters. Twenty-four ${ }^{137} \mathrm{Cs}$ contaminated and heattreated $\left(8.8 \mathrm{~cm}^{2}\right.$ of surface) coupons were subjected to various conditions using $120 \mathrm{~mL}$ of solution for each coupon $\left(136 \mathrm{~L} / \mathrm{m}^{2}\right)$. Coupons were tested under 12 conditions by varying the $\mathrm{Ce}$ (IV) $/ \mathrm{HNO}_{3}$ concentration $[0.005 \mathrm{M}$ to $0.02 \mathrm{M} \mathrm{Ce}(\mathrm{IV}) / 0.2 \mathrm{M}$ to $1 \mathrm{M} \mathrm{HNO}$ ], the contact time $(3$ to $12 \mathrm{~h})$, and the solution temperature $\left(25^{\circ}\right.$ to $\left.90^{\circ} \mathrm{C}\right)$. The loss in coupon metal and oxide weight was determined using a five-place analytical balance (Appendix, Table A.1). The loss of surface radioactive contamination was determined by gamma counting the coupon surface before and after decontamination (Appendix, Tables A.3 and A.4). The coupons were then smeared on both sides to determine the decontamination efficiency as a function of test conditions (compared to WAPS) (DOE 1990) (Appendix, Table A.4).

The test conditions for coupons 15 and 16 were assumed to be the "base case" to which all other conditions were compared. The "base case" conditions were previously selected (Bray 1988) as the minimum conditions to adequately decontaminate the SS canisters. Those conditions were $65^{\circ} \mathrm{C}, 6 \mathrm{~h}$, and 
1.4 moles of $\mathrm{Ce}(\mathrm{IV}) / \mathrm{m}^{2}\left(0.01\right.$ moles of $\left.\mathrm{Ce}(\mathrm{IV}) / 120 \mathrm{~mL} / 8.8 \mathrm{~cm}^{2}\right)$ to remove $3 \mu \mathrm{m}$ of SS surface. The "base case" was tested against four variables: contact time, temperature, $\mathrm{Ce}(\mathrm{IV})$ concentration, and $\mathrm{HNO}_{3}$ concentration.

In certain cases, a layer of loosely held oxide remained on the SS surface after removal of the coupon from the test solution. Low-pressure water from a standard laboratory wash bottle was used to rinse each coupon, usualiy removing the loosely held oxide. In several tests that were not "base case," the oxide was only partially removed or not at all. Effective rinsing requirements is an area of engineering uncertainty that will be resolved when the decontamination process is scaled up by a factor of $5,000: 1$ by the WVDP and tested in FY 1992 at West Valley using full-scale glass-filled canisters. West Valley will test a series of jet nozzles for washing the decontaminated canister free of any loose oxide and decontamination solution. Ultrasonic agitation has been suggested as an alternative or an addition to spray nozzles, but has not been selected for the initial series of full-scale tests.

\subsection{EFFECT OF Ce(IV) CONCENTRATION}

The results show (at a contact time of $6 \mathrm{~h}$, a temperature of $65^{\circ} \mathrm{C}$, and at an acid concentration of $0.5 \mathrm{M} \mathrm{HNO}_{3}$ ) a direct relationship between the $\mathrm{Ce}$ (IV) concentration and the Cs decontamination factor (DF), the wipe results $\left(\mathrm{dpm} / 100 \mathrm{~cm}^{2}\right)$, and the penetration depth $(\mu \mathrm{m})$. These results are presented in Table 5.1 and Figure 5.1. A concentration of $0.01 \mathrm{M} \mathrm{Ce}$ (IV) satisfies the goal of $<2,200 \mathrm{dpm} / \mathrm{cm}^{2}$ with the chemical milling of $>2 \mu \mathrm{m}$ of SS.

\subsection{EFFECT OF TEMPERATURE}

The rate of SS dissolution is directly dependent on the solution temperature after $6 \mathrm{~h}$ of contact, at $0.01 \mathrm{M} \mathrm{Ce}(\mathrm{IV}) / 0.5 \mathrm{M} \mathrm{HNO}{ }_{3}$, between $25^{\circ}$ and $65^{\circ} \mathrm{C}$ (Table 5.2). The results for tests at $25^{\circ}$ and $45^{\circ} \mathrm{C}$ exceeded the smear limit of $\left\langle 2,200 \mathrm{dpm}\right.$ gamma $/ 100 \mathrm{~cm}^{2}$ (Figure 5.2). The results at $90^{\circ} \mathrm{C}$, al though meeting the smear limit, are inconsistent with the other results and may be due to a precipitate found in the final solution (Appendix, Table A.3). 
TABLE 5.1. Ce(IV) Concentration (Constant: $6 \mathrm{~h}, 65^{\circ} \mathrm{C}, 0.5 \mathrm{M} \mathrm{HNO}_{3}$ ) Coupon No. Ce(IV), M $137 \mathrm{Cs}, \mathrm{DF} \quad \mathrm{dpm} / 100 \mathrm{~cm}^{2}$ Penetration, um

35

25

26

15

16

23

24
0

0.005

0.01

0.02
6

16

11

1,113

977

2,296

2,003
5.2E4

$6.3 E 4$

$1.4 \mathrm{E} 5$

772

783

NDA ${ }^{(a)}$

NDA
0.05

1.2

1.1

2.5

2.4

4.7

4.9

(a) No Detectable Activity (Detection limit for this size and geometry of coupon is estimated to be approximately $1 \mathrm{dpm} / 100 \mathrm{~cm}^{2}$.)

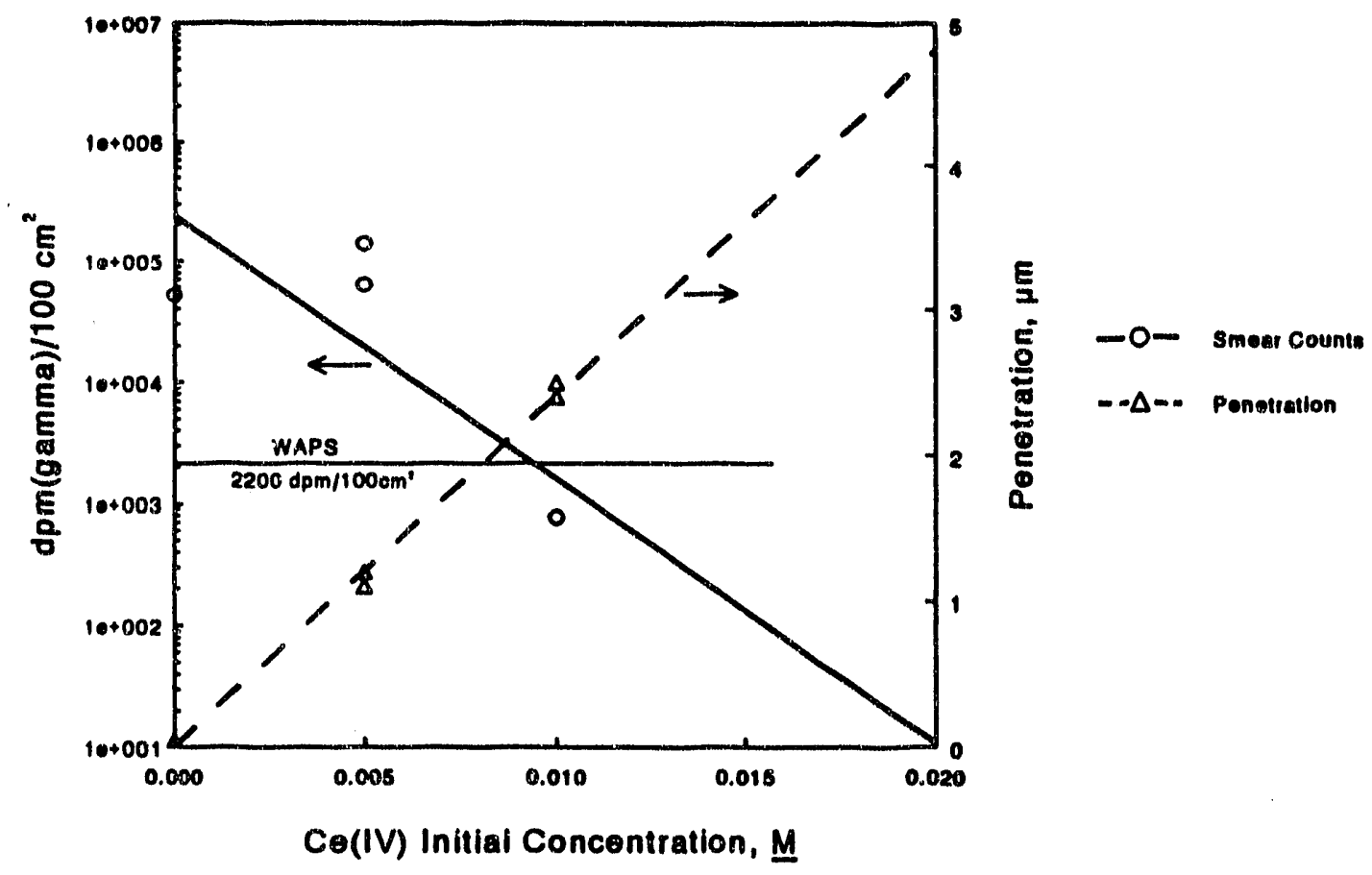

FIGURE 5.1. Smear Count $\left(\mathrm{dpm} / 100 \mathrm{~cm}^{2}\right)$ and Penetration $(\mu \mathrm{m})$ as a Function of the $\mathrm{Ce}$ (IV) Concentration. Conditions: contact time, $6 \mathrm{~h} ; 0.5 \mathrm{M}$ $\mathrm{HNO}_{3}$; volume, $120 \mathrm{~mL}$; surface area, $8.8 \mathrm{~cm}^{2}$; temperature, $65^{\circ} \mathrm{C}$ 
IABLE 5.2. Temperature [Constant: $6 \mathrm{~h}, 0.5 \mathrm{MHNO}, 0.01 \mathrm{M} \mathrm{Ce}(\mathrm{IV})$ ] Coupon No. Temperature, ${ }^{\circ} \mathrm{C} \quad{ }^{137} \mathrm{Cs}$, DF $\mathrm{dpm} / 100 \mathrm{~cm}^{2}$ Penetration, $\mathrm{mm}$

11

12

13

14

15

16

17

18
25

45

65

90
3

421

10

1,113

977

1,096

391
$3.7 E 5$

$4.8 \mathrm{E} 5$

2. $8 \mathrm{E} 3$

2.1E5

772

783

977

1,340
0.36

0.35

1.8

1.6

2.5

2.4

2.0

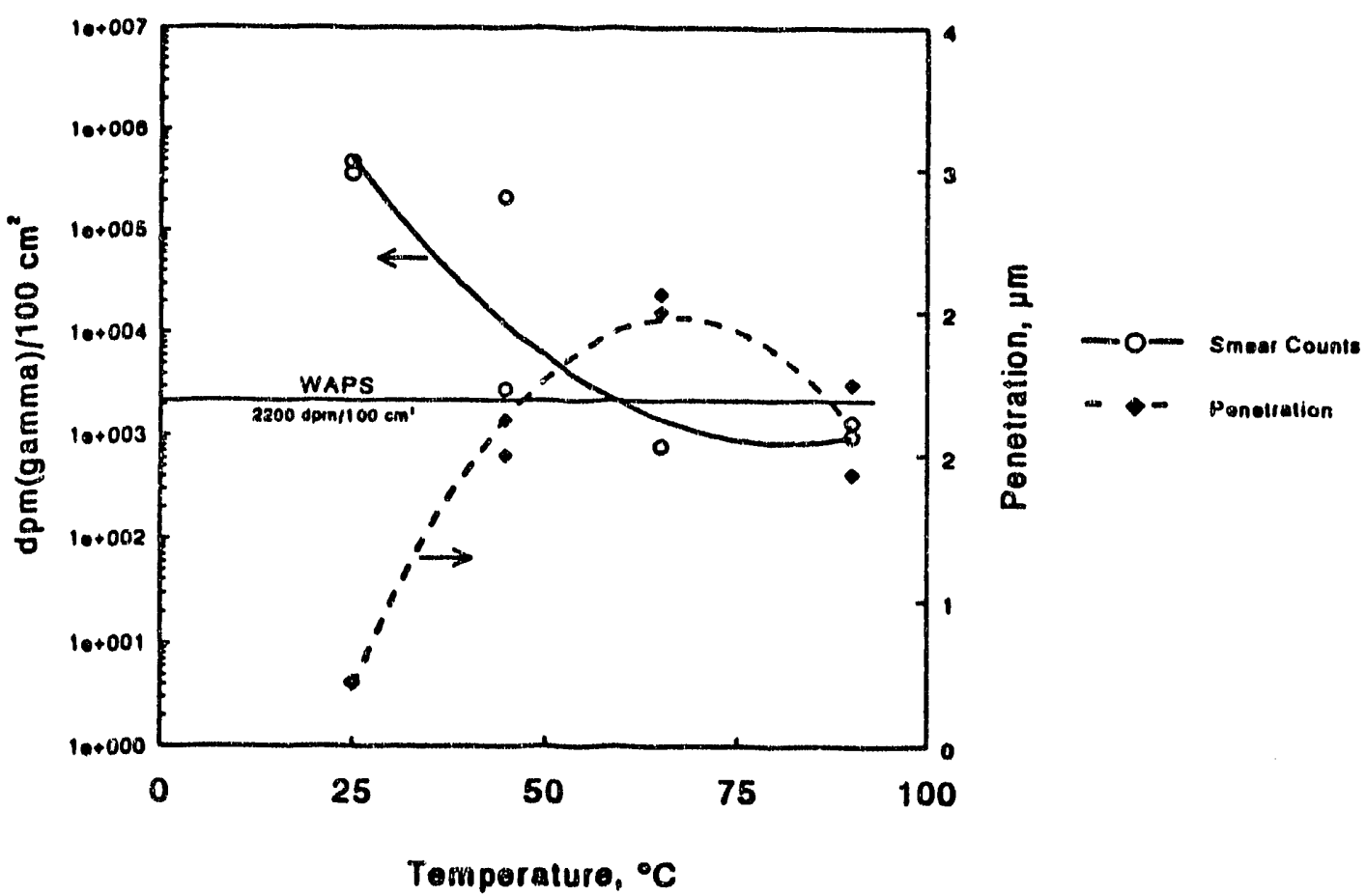

FIGURE 5.2. Smear Count (dpm/100 $\left.\mathrm{cm}^{2}\right)$ and Penetration ( $\left.\mu \mathrm{m}\right)$ as a Function of Temperature. Conditions: contact time, $6 \mathrm{~h} ; 0.5 \mathrm{M} \mathrm{HNO}_{3} ; 0.01 \mathrm{M}$ Ce (IV); volume, $120 \mathrm{~mL}$; surface area, $8.8 \mathrm{~cm}^{2}$

\subsection{EFFECT OF ACID CONCENTRATION}

Previous work (Bray 1988) had not evaluated the effect of acid concentration. In this study, the acid concentration was varied from 0.2 to $1 \mathrm{M} \mathrm{HNO}$ (Table 5.3). The test solutions containing $0.2 \mathrm{M} \mathrm{HNO}_{3}$ were very 
TABLE 5.3. Acid Concentration [Constant: $6 \mathrm{~h}, 0.01 \mathrm{M} \mathrm{Ce}$ (IV)] Coupon No. $\mathrm{HNO}_{32} \mathrm{M} \quad{ }^{137} \mathrm{Cs}, \mathrm{DF} \quad \mathrm{dpm} / 100 \mathrm{~cm}^{2}$ Penetration, $\mu \mathrm{m}$

$\begin{array}{rrrll}21 & 0.2 & 7 & 1.3 \mathrm{E} 5 & 0.19 \\ 22 & & 7 & 1.5 \mathrm{EE} & 0.25 \\ 15 & 0.5 & 1,113 & 772 & 2.5 \\ 16 & & 977 & 783 & 2.4 \\ 19 & 1.0 & 1,852 & 193 & \\ 20 & & 1,914 & \text { NDA }^{(a)} & 2.5 \\ & & & & \end{array}$

(a) No Detectable Activity (detection limit $\sim 1 \mathrm{dpm} / 100 \mathrm{~cm}^{2}$ ).

cloudy. Based on visual observations, the coupons appeared to have been coated with a cerium salt precipitate, resulting in a poor C.s DF and a lack of SS dissolution. Cerium does appear to have limited solubility in diute $\mathrm{HNO}_{3}$. Additional work is needed in this area. It is recommended that the acid concentration be maintained at 0.5 to $1 \mathrm{M} \mathrm{HNO} \mathrm{H}_{3}\left(1 \mathrm{M} \mathrm{HNO}_{3}\right.$ conditions gave the best results).

\subsection{EFFECT OF CONTACT TIME}

The solution coupon-contact time was varied from 3 to $12 \mathrm{~h}$ at $65^{\circ} \mathrm{C}$ and $0.5 \mathrm{M} \mathrm{HNO}_{3}$, for 0.01 and $0.02 \mathrm{M} \mathrm{Ce}$ (IV) (see Table 5.4). Under all conditions, the coupons were deterinined to be decontaminated to $<2,200 \mathrm{dpm}$ gamma $/ 100 \mathrm{~cm}^{2}$ (Figure 5.3). The SS dissolution (penetration depth) was constant after $6 \mathrm{~h}$ (Figure 5.4). 
IABLE 5.4. Contact Time (Constant: $65^{\circ} \mathrm{C}, 0.5 \mathrm{M} \mathrm{HNO}{ }_{3}$ )

\begin{tabular}{|c|c|c|c|c|c|}
\hline Coupon No. & Contact Time, $h$ & $\mathrm{Ce}$ (IV), M & ${ }^{137} \mathrm{CS}, \mathrm{DF}$ & $\mathrm{dpm} / 100 \mathrm{~cm}^{2}$ & Penetration, um \\
\hline $\begin{array}{l}27 \\
28\end{array}$ & 3 & 0.01 & $\begin{array}{l}1,512 \\
1,258\end{array}$ & $\begin{array}{l}386 \\
N^{\prime} A^{(a)}\end{array}$ & $\begin{array}{l}2.2 \\
2.1\end{array}$ \\
\hline $\begin{array}{l}15 \\
16\end{array}$ & 6 & 0.01 & $\begin{array}{r}1,113 \\
977\end{array}$ & $\begin{array}{l}772 \\
783\end{array}$ & $\begin{array}{l}2.5 \\
2.4\end{array}$ \\
\hline $\begin{array}{l}29 \\
30\end{array}$ & 12 & 0.01 & $\begin{array}{r}242 \\
2,537\end{array}$ & $\begin{array}{l}\text { NDA } \\
\text { NDA }\end{array}$ & $\begin{array}{l}2.5 \\
2.5\end{array}$ \\
\hline $\begin{array}{l}31 \\
32\end{array}$ & 3 & 0.02 & $\begin{array}{l}1,840 \\
1,220\end{array}$ & $\begin{array}{l}125 \\
\text { NDA }\end{array}$ & $\begin{array}{l}3.2 \\
3.3\end{array}$ \\
\hline $\begin{array}{l}23 \\
24\end{array}$ & 6 & 0.02 & $\begin{array}{l}2,296 \\
2,003\end{array}$ & $\begin{array}{l}\text { NDA } \\
\text { NDA }\end{array}$ & $\begin{array}{l}4.7 \\
4.9\end{array}$ \\
\hline $\begin{array}{l}33 \\
34\end{array}$ & 12 & 0.02 & $\begin{array}{l}939 \\
935\end{array}$ & $\begin{array}{l}\text { NDA } \\
\text { NDA }\end{array}$ & $\begin{array}{l}4.8 \\
4.6\end{array}$ \\
\hline
\end{tabular}

(a) NDA - No Detectable Activity (detection limit $\sim 1 \mathrm{dpm} / 100 \mathrm{~cm}^{2}$ ).

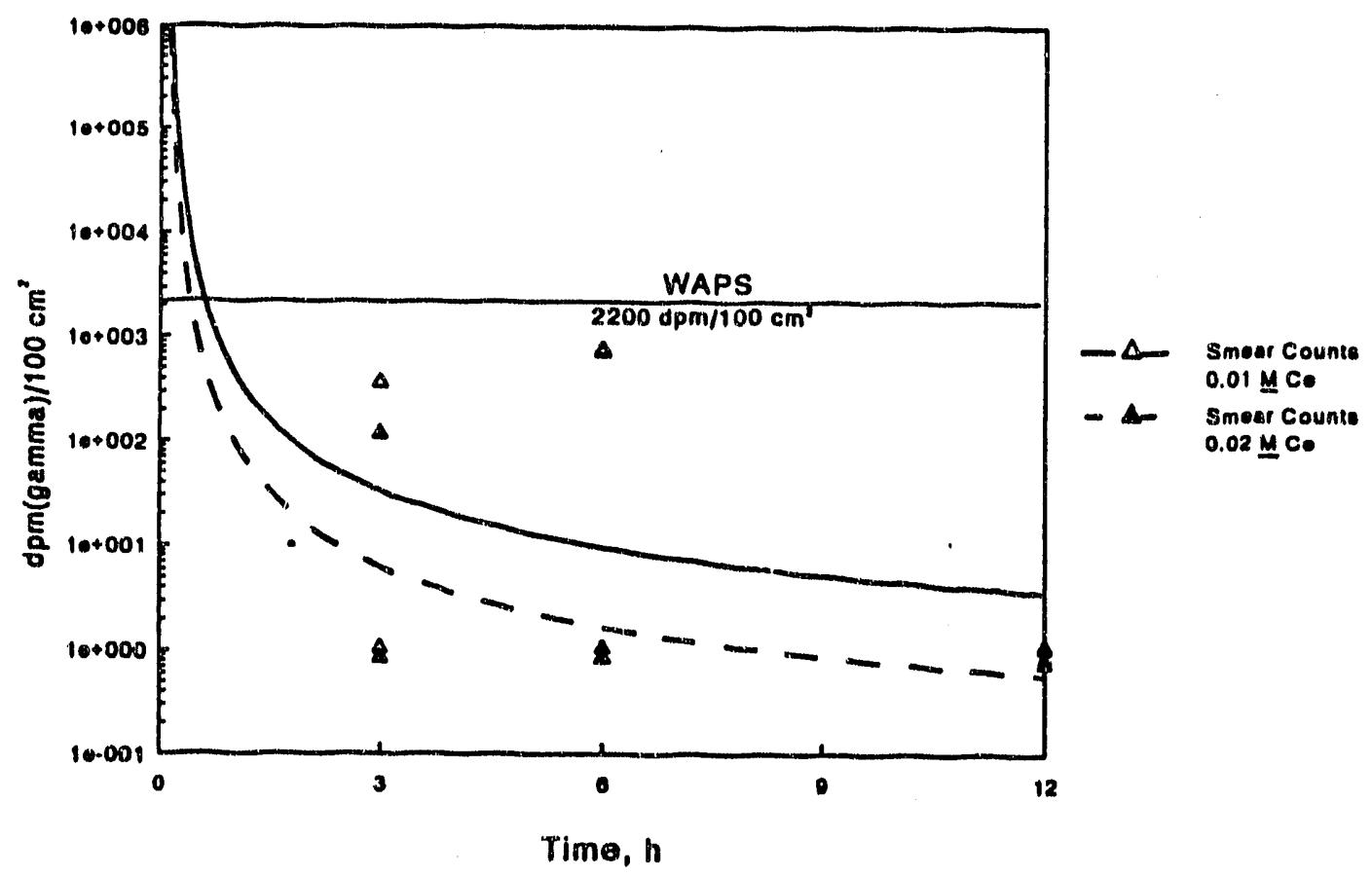

FIGURE 5.3. Smear Count $\left(\mathrm{dpm} / 100 \mathrm{~cm}^{2}\right)$ as a Function of Contact Time. Conditions: $0.5 \mathrm{M} \mathrm{HNO}$; volume, $120 \mathrm{~mL}$; surface area, $8.8 \mathrm{~cm}^{2}$; temperature, $65^{\circ} \mathrm{C}$. Curves shown are least-squares fit of power curve to data. 


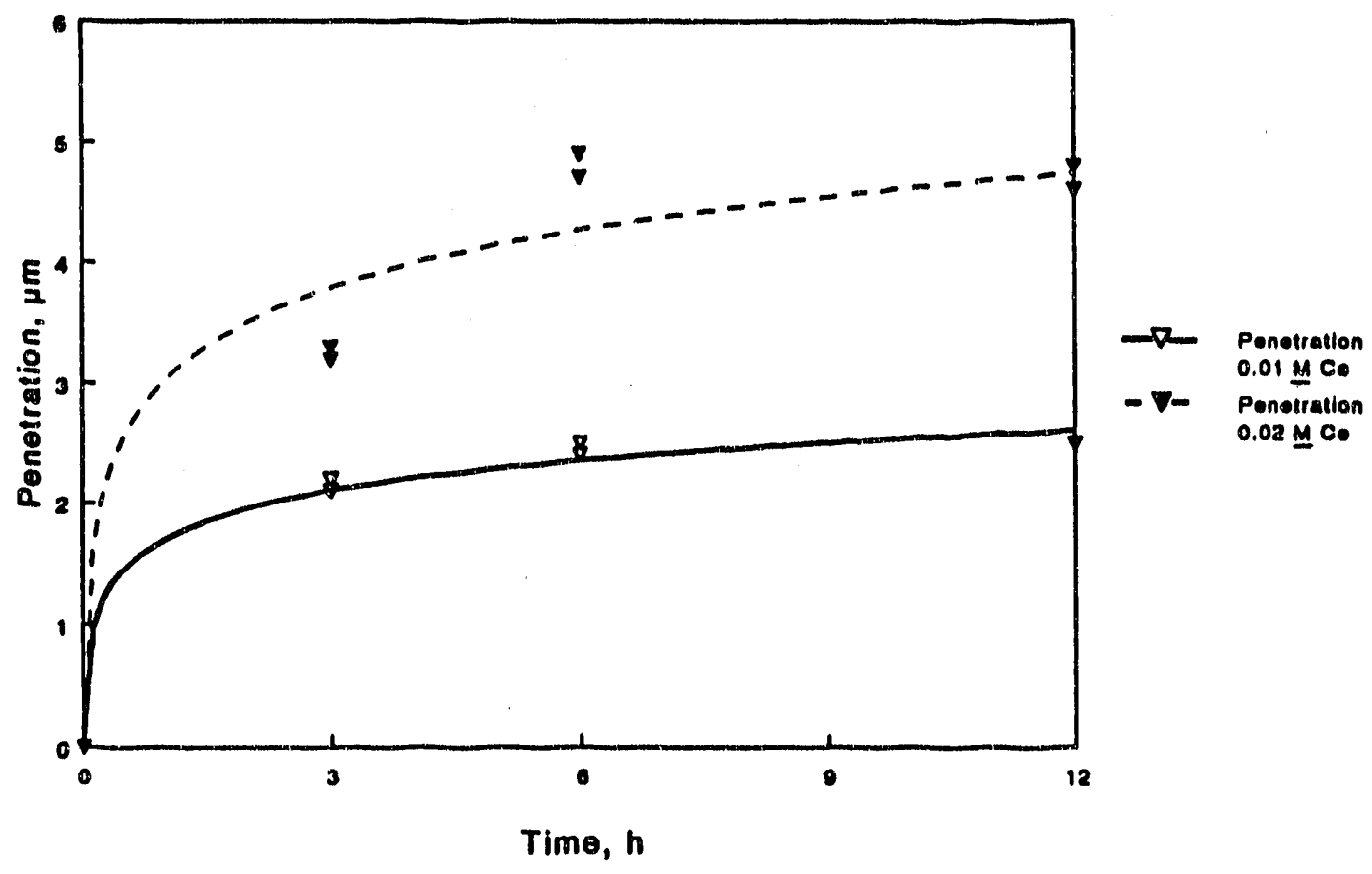

FIGURE 5.4 Calculated Penetration ( $\mu \mathrm{m})$ as a Function of Contact Time. Conditions: $0.5 \mathrm{M} \mathrm{HNO}_{3}$; volume, $120 \mathrm{~mL}$; surface area, $8.8 \mathrm{~cm}^{2}$; temperature, $65^{\circ} \mathrm{C}$. Curves shown are least-squares fit of log curve to data. 


\subsection{REFERENCES}

Bray, L. A. 1988. Development of a Chemical Process Using Nitric Acid Cerium (IV) for Decontamination of High-Level Waste Canisters. PNL-6567, Pacific Northwest Laboratory, Richland, Washington.

Bray, L. A., and J. M. Seay. 1988. Development and Design Application of Cerium (IV) Decontamination Process. PNL-SA-15962, Pacific Northwest Laboratory, Richland, Washington.

Rankin, W. N. 1982. "Decontamination Processes for Waste Glass Canisters." Nuclear Technology, Vol. 59.

U.S. Department of Energy (DOE). 1990. Waste Acceptance Preliminary Specifications for High-Level Waste Glass, YMP/90-65, Office of Civilian Radioactive Waste Management, Department of Energy, Washington, D.C. 
APPENDIX $A$

SUMMARY OF DECONTAMINATION TEST CONDITIONS, RESULTS, AND OBSERVATIONS 
IABLE A.l. Coupon Weight Values Before and After Decontamination

\begin{tabular}{|c|c|c|c|c|c|c|c|c|c|c|c|}
\hline Heen & $\begin{array}{l}\text { Initial } \\
\text { Veight. } \\
\text { ge. }\end{array}$ & $\begin{array}{l}\text { Weight } \\
\text { After } \\
\text { Oxidg.a }\end{array}$ & $\begin{array}{c}\text { Wetght } \\
\text { of } \\
\text { oxide. }\end{array}$ & $\begin{array}{l}\text { Velght } \\
\text { After } \\
\text { Celliv). }\end{array}$ & $\begin{array}{c}\frac{\text { Loss }}{\text { Inftial }} \\
\text { Weight. } \\
\text { Q } \\
\end{array}$ & $\begin{array}{l}\text { gf } \\
\text { clixide } \\
\text { Weight, } \\
\text { g }\end{array}$ & $\begin{array}{l}\text { Contact } \\
\text { If } 1 \text { me, h }\end{array}$ & $\begin{array}{l}\text { Tempera- } \\
\text { ture. C }\end{array}$ & $\mathrm{Ce}(\mathrm{IV})$, & $\mathrm{H}^{\mathrm{HNO}_{3}}$ & $\begin{array}{l}\text { Pene- } \\
\text { irafign. } \\
\text { phas }\end{array}$ \\
\hline $\begin{array}{l}11 \\
12\end{array}$ & $\begin{array}{l}4.26441 \\
4.2846 \%\end{array}$ & $\begin{array}{l}4.26914 \\
4.28942\end{array}$ & $\begin{array}{l}0.08473 \\
0.09480\end{array}$ & $\begin{array}{l}4.26187 \\
4.28218\end{array}$ & $\begin{array}{l}9.60254 \\
8.80244\end{array}$ & $\begin{array}{l}0.00727 \\
0.09724\end{array}$ & 6 & 25 & $0.01^{(b)}$ & 0.5 & $\begin{array}{l}0.36 \\
0.35\end{array}$ \\
\hline $\begin{array}{l}13 \\
14\end{array}$ & $\begin{array}{l}4.28577 \\
4.24138\end{array}$ & $\begin{array}{l}4.29141 \\
4.24556\end{array}$ & $\begin{array}{l}0.09564 \\
0.00418\end{array}$ & $\begin{array}{l}4.27294 \\
4.23685\end{array}$ & $\begin{array}{r}0.01283 \\
0.01133\end{array}$ & $\begin{array}{l}0.01817 \\
0.01551\end{array}$ & 6 & 45 & 0.01 & 0.5 & $\begin{array}{l}1.8 \\
1.6\end{array}$ \\
\hline $\begin{array}{l}15 \\
16\end{array}$ & $\begin{array}{l}4.25295 \\
4.28200\end{array}$ & $\begin{array}{l}1.25750 \\
4.28487\end{array}$ & $\begin{array}{l}\text { c.08455 } \\
\text { 4.0287 }\end{array}$ & $\begin{array}{l}4.23537 \\
4.26489\end{array}$ & $\begin{array}{l}9.01758 \\
0.01728\end{array}$ & $\begin{array}{l}0.62213 \\
0.62067\end{array}$ & 6 & 65 & 0.01 & 0.5 & $\begin{array}{l}2.5 \\
2.4\end{array}$ \\
\hline $\begin{array}{l}17 \\
18\end{array}$ & $\begin{array}{l}4.23388 \\
4.23134\end{array}$ & $\begin{array}{l}4.23795 \\
4.23595\end{array}$ & $\begin{array}{l}\text { C.03497 } \\
\text { V. }\end{array}$ & $\begin{array}{r}4.21969 \\
4.22682\end{array}$ & $\begin{array}{l}8.81419 \\
8.81652\end{array}$ & $\begin{array}{l}0.018: 26 \\
0.01513\end{array}$ & 6 & 90 & .11 & 0.5 & $\begin{array}{l}2.0 \\
1.5\end{array}$ \\
\hline $\begin{array}{l}19 \\
28\end{array}$ & $\begin{array}{r}4.31276 \\
4.30168\end{array}$ & $\begin{array}{l}4.31770 \\
4.38584\end{array}$ & $\begin{array}{l}1.04944 \\
8.08416\end{array}$ & $\begin{array}{l}4.29536 \\
4.28396\end{array}$ & $\begin{array}{l}0.01748 \\
8.01772\end{array}$ & $\begin{array}{l}0.021234 \\
0.02188\end{array}$ & 6 & 65 & 0.01 & 1.8 & $\begin{array}{l}2.5 \\
2.5\end{array}$ \\
\hline $\begin{array}{l}21 \\
22\end{array}$ & $\begin{array}{l}4.24462 \\
4.16721\end{array}$ & $\begin{array}{l}4.24887 \\
4.17248\end{array}$ & $\begin{array}{l}8.0485 \\
0.06419\end{array}$ & $\begin{array}{l}4.24267 \\
4.16543\end{array}$ & $\begin{array}{l}0.90135 \\
0.00178\end{array}$ & $\begin{array}{l}0.00620 \\
6.08597\end{array}$ & 6 & 65 & 0.01 & 0.2 & $\begin{array}{l}0.19 \\
0.25\end{array}$ \\
\hline $\begin{array}{l}23 \\
24\end{array}$ & $\begin{array}{l}4.24872 \\
+.38233\end{array}$ & $\begin{array}{r}4.25363 \\
4.30596\end{array}$ & $\begin{array}{l}0.01491 \\
0.86363\end{array}$ & $\begin{array}{l}4.21541 \\
4.2675 \%\end{array}$ & $\begin{array}{l}0.83331 \\
8.83476\end{array}$ & $\begin{array}{l}0.03822 \\
0.03839\end{array}$ & 6 & 65 & $9.02^{(c)}$ & 0.5 & $\begin{array}{l}4.7 \\
4.9\end{array}$ \\
\hline $\begin{array}{l}25 \\
26\end{array}$ & $\begin{array}{l}4.27682 \\
4.25924\end{array}$ & $\begin{array}{r}4.28014 \\
4.26418\end{array}$ & 9. 14332 & $\begin{array}{l}4.26839 \\
4.25131\end{array}$ & $\begin{array}{l}\text { C. } 188843 \\
\text { e. } 89793\end{array}$ & $\begin{array}{l}0.01175 \\
0.01287\end{array}$ & 6 & 65 & 0.685 & 0.5 & $\begin{array}{l}1.2 \\
1.1\end{array}$ \\
\hline $\begin{array}{l}27 \\
28\end{array}$ & $\begin{array}{r}4.31231 \\
4.28031\end{array}$ & $\begin{array}{l}4.31628 \\
4.28368\end{array}$ & $\begin{array}{l}\text { 1. 9.389 } \\
\text { 6. } 28337\end{array}$ & $\begin{array}{l}4.29696 \\
4.26547\end{array}$ & $\begin{array}{l}0.01535 \\
0.01484\end{array}$ & $\begin{array}{l}0.91924 \\
0.81821\end{array}$ & 3 & 65 & 0.01 & 0.5 & $\begin{array}{l}2.2 \\
2.1\end{array}$ \\
\hline $\begin{array}{l}29 \\
39\end{array}$ & $\begin{array}{l}4.29865 \\
4.29443\end{array}$ & $\begin{array}{l}4.30344 \\
4.29841\end{array}$ & $\begin{array}{r}0.0479 \\
0.00398\end{array}$ & $\begin{array}{l}4.281333 \\
4.27683\end{array}$ & $\begin{array}{l}0.01732 \\
0.01755\end{array}$ & $\begin{array}{l}0.112211 \\
0.12153\end{array}$ & 12 & 65 & 0.01 & 0.5 & $\begin{array}{l}2.5 \\
2.5\end{array}$ \\
\hline $\begin{array}{l}31 \\
32\end{array}$ & $\begin{array}{l}4.23578 \\
4.31687\end{array}$ & $\begin{array}{l}4.23982 \\
4.31631\end{array}$ & $\begin{array}{l}0.08404 \\
0.00544\end{array}$ & $\begin{array}{l}4.21288 \\
4.28772\end{array}$ & $\begin{array}{l}0.62299 \\
0.82315\end{array}$ & $\begin{array}{l}0.0269 A \\
0.02859\end{array}$ & 3 & 65 & 0.62 & 0.5 & $\begin{array}{l}3.2 \\
3.3\end{array}$ \\
\hline $\begin{array}{l}33 \\
34\end{array}$ & $\begin{array}{l}4.198988 \\
4.24933\end{array}$ & $\begin{array}{l}4.28465 \\
4.25 \$ 22\end{array}$ & $\begin{array}{l}0.0567 \\
0.01889\end{array}$ & $\begin{array}{l}4.16536 \\
4.21712\end{array}$ & $\begin{array}{l}0.03362 \\
0.03221\end{array}$ & $\begin{array}{l}0.03929 \\
0.03716\end{array}$ & 12 & 65 & 0.82 & 0.5 & $\begin{array}{l}4.8 \\
4.6\end{array}$ \\
\hline 35 & 4.19397 & 4.19850 & 0.00453 & 4.19359 & 0.00038 & 0.0491 & 6 & 65 & ] & 0.5 & 0.85 \\
\hline
\end{tabular}

(b) $\frac{\text { Loss of SS(meta }), g}{\left.\text { SpG SS(B.02 } \mathrm{g} / \mathrm{cm}^{3}\right)} \times \frac{10^{4} \mu \mathrm{m} / \mathrm{cm}}{\text { Syrface Area }\left(8.8 \mathrm{~cm}^{2}\right)}=\mu \mathrm{m}$ of matal dissoived.

(b) 11 moles Ce(IV)/8.8 $\mathrm{cm}_{2}^{2}=1.36 \mathrm{moles} \mathrm{Ce}$ (IV) $/ \mathrm{mm}_{2}^{2}$.

(c) . moles $\mathrm{Ce}\left(\right.$ IV $/ 8.8 \mathrm{~cm}^{2}=2.73 \mathrm{moles} \mathrm{Co}(\mathrm{IV}) / \mathrm{m}^{2}$. 
IABLE A.2. Ce(IV) Decontamination Test Conditions

\begin{tabular}{|c|c|c|c|c|c|}
\hline Coupon & $\begin{array}{l}\text { Tempera- } \\
\text { ture. }{ }^{\circ} \mathrm{C}\end{array}$ & $0.542 \mathrm{MCe}(1 \mathrm{~V}) \mathrm{mL}$ & $15.7 \mathrm{M} \mathrm{HHO}_{3} \mathrm{~mL}$ & Yol. $\mathrm{ml}$ & Contact Time, $h$ \\
\hline $\begin{array}{l}11 \\
12\end{array}$ & $\begin{array}{l}25 \\
25\end{array}$ & $\begin{array}{l}2.21(0.01) \\
2.21(0.01)\end{array}$ & $\begin{array}{l}3.61(0.5) \\
3.61(0.5)\end{array}$ & $\begin{array}{l}120 \\
120\end{array}$ & $\begin{array}{l}6 \\
6\end{array}$ \\
\hline $\begin{array}{l}13 \\
14\end{array}$ & $\begin{array}{l}45 \\
45\end{array}$ & $\begin{array}{l}2.21(0.01) \\
2.21(0.01)\end{array}$ & $\begin{array}{l}3.61(0.5) \\
3.61(0.5)\end{array}$ & $\begin{array}{l}120 \\
120\end{array}$ & $\begin{array}{l}6 \\
6\end{array}$ \\
\hline $\begin{array}{l}15 \\
16\end{array}$ & $\begin{array}{l}65 \\
65\end{array}$ & $\begin{array}{l}2.21(0.01) \\
2.21(0.01)\end{array}$ & $\begin{array}{ll}3.61 & (0.5) \\
3.61 & (0.5)\end{array}$ & $\begin{array}{l}120 \\
120\end{array}$ & $\begin{array}{l}6 \\
6\end{array}$ \\
\hline $\begin{array}{l}17 \\
18\end{array}$ & $\begin{array}{l}90 \\
90\end{array}$ & $\begin{array}{l}2.21(0.01) \\
2.21(0.01)\end{array}$ & $\begin{array}{l}3.61(0.5) \\
3.61(0.5)\end{array}$ & $\begin{array}{l}120 \\
120\end{array}$ & $\begin{array}{l}6 \\
6\end{array}$ \\
\hline $\begin{array}{l}19 \\
29\end{array}$ & $\begin{array}{l}65 \\
65\end{array}$ & $\begin{array}{l}2.21(9.01) \\
2.21(0.01)\end{array}$ & $\begin{array}{l}7.43(1.0) \\
7.43(1.0)\end{array}$ & $\begin{array}{l}120 \\
120\end{array}$ & $\begin{array}{l}6 \\
6\end{array}$ \\
\hline $\begin{array}{l}21 \\
22\end{array}$ & $\begin{array}{l}65 \\
65\end{array}$ & $\begin{array}{l}2.21(0.01) \\
2.21(0.01)\end{array}$ & $\begin{array}{l}1.31(0.2) \\
1.31(0.2)\end{array}$ & $\begin{array}{l}120 \\
120\end{array}$ & $\begin{array}{l}6 \\
6\end{array}$ \\
\hline $\begin{array}{l}23 \\
24\end{array}$ & $\begin{array}{l}65 \\
65\end{array}$ & $\begin{array}{l}4.42(0.82) \\
4.42(0.62)\end{array}$ & $\begin{array}{l}3.39(0.5) \\
3.39(0.5)\end{array}$ & $\begin{array}{l}120 \\
120\end{array}$ & $\begin{array}{l}6 \\
6\end{array}$ \\
\hline $\begin{array}{l}25 \\
28\end{array}$ & $\begin{array}{l}65 \\
65\end{array}$ & $\begin{array}{l}1.10(0.095) \\
1.10(0.095)\end{array}$ & $\begin{array}{l}3.72(0.5) \\
3.72(0.5)\end{array}$ & $\begin{array}{l}120 \\
120\end{array}$ & $\begin{array}{l}6 \\
6\end{array}$ \\
\hline $\begin{array}{l}27 \\
28\end{array}$ & $\begin{array}{l}65 \\
65\end{array}$ & $\begin{array}{l}2.21(0.01) \\
2.21(0.01)\end{array}$ & $\begin{array}{l}3.61(0.5) \\
3.61(0.5)\end{array}$ & $\begin{array}{l}120 \\
120\end{array}$ & $\begin{array}{l}3 \\
3\end{array}$ \\
\hline $\begin{array}{l}29 \\
30\end{array}$ & $\begin{array}{l}65 \\
65\end{array}$ & $\begin{array}{ll}2.21 & (0.01) \\
2.21 & (0.01)\end{array}$ & $\begin{array}{ll}3.61 & (0.5) \\
3.61 & (0.5)\end{array}$ & $\begin{array}{l}120 \\
120\end{array}$ & $\begin{array}{l}12 \\
12\end{array}$ \\
\hline $\begin{array}{l}31 \\
32\end{array}$ & $\begin{array}{l}65 \\
65\end{array}$ & $\begin{array}{l}4.42(0.02) \\
4.42(0.02)\end{array}$ & $\begin{array}{ll}3.39 & (0.5) \\
3.39 & (0.5)\end{array}$ & $\begin{array}{l}120 \\
120\end{array}$ & $\begin{array}{l}3 \\
3\end{array}$ \\
\hline $\begin{array}{l}33 \\
34\end{array}$ & $\begin{array}{l}65 \\
65\end{array}$ & $\begin{array}{l}4.42(0.02) \\
4.42(0.02)\end{array}$ & $\begin{array}{l}3.39(0.5) \\
3.39(0.5)\end{array}$ & $\begin{array}{l}120 \\
120\end{array}$ & $\begin{array}{l}12 . \\
12\end{array}$ \\
\hline 35 & 65 & $-0-$ & $3.82(0.5)$ & 120 & 6 \\
\hline
\end{tabular}


TABLE A.4. Decontamination Smear Results

\begin{tabular}{|c|c|c|c|c|c|c|c|c|c|}
\hline Coupon & $\begin{array}{l}\text { Initial } \\
\text { Coupon } \\
\text { Count. } \\
\text { den Cs } \\
\end{array}$ & $\begin{array}{l}\text { Coupon (a) } \\
\text { After } \\
\text { Treatment, } \\
\text { dion Cs } \\
\end{array}$ & $\begin{array}{l}{ }^{137} \mathrm{Cs} \\
\mathrm{DF}\end{array}$ & $\begin{array}{l}\text { Smear (b) } \\
\text { Count, } \\
\text { dom Cs } \\
\end{array}$ & $\begin{array}{l}\mathrm{dpg}(1 \mathrm{p} p \\
\mathrm{cm}\end{array}$ & $\begin{array}{l}\text { Contact } \\
\text { Iime } h\end{array}$ & $\begin{array}{l}\text { Tempera- } \\
\text { ture. }{ }^{\circ} \mathrm{C}\end{array}$ & $\mathrm{Ce}(I V), \mathrm{M}$ & $\mathrm{HNO}_{3} \mathrm{M}$ \\
\hline $\begin{array}{l}11 \\
12\end{array}$ & $\begin{array}{l}7.75 E 5 \\
7.56 E 5\end{array}$ & $\begin{array}{l}2.46 E 5 \\
2.37 E 5\end{array}$ & $\begin{array}{l}3 \\
3\end{array}$ & $\begin{array}{l}3.23 E 4 \\
3.86 E 4\end{array}$ & $\begin{array}{l}3.67 E 5 \\
4.78 E 5\end{array}$ & 6 & 25 & 0.01 & 0.5 \\
\hline $\begin{array}{l}13 \\
14\end{array}$ & $\begin{array}{l}7.37 E 5 \\
1.13 E 6\end{array}$ & $\begin{array}{l}1.75 E 3 \\
1.11 E 5\end{array}$ & $\begin{array}{r}421 \\
10\end{array}$ & $\begin{array}{r}243 \\
1.88 E 4\end{array}$ & $\begin{array}{l}2.80 E 3 \\
2.13 E 5\end{array}$ & 6 & 45 & 0.01 & 0.5 \\
\hline $\begin{array}{l}15 \\
16\end{array}$ & $\begin{array}{l}6.89 E 5 \\
7.25 E 5\end{array}$ & $\begin{array}{l}601 \\
742\end{array}$ & $\begin{array}{r}1.113 \\
977\end{array}$ & $\begin{array}{l}68 \pm 18 \% \\
69 \pm 19 \%\end{array}$ & $\begin{array}{l}772 \\
783\end{array}$ & 6 & 65 & 0.01 & 0.5 \\
\hline $\begin{array}{l}17 \\
18\end{array}$ & $\begin{array}{l}1.16 E 6 \\
6.94 E 5\end{array}$ & $\begin{array}{l}1,658 \\
1,776\end{array}$ & $\begin{array}{r}1,095 \\
391\end{array}$ & $\begin{array}{l}86 \pm 17 \% \\
18 \pm 13 \%\end{array}$ & $\begin{array}{r}977 \\
1.340\end{array}$ & 6 & 90 & 0.01 & 9.5 \\
\hline $\begin{array}{l}19 \\
29\end{array}$ & $\begin{array}{l}7.37 E 5 \\
6.63 E 5\end{array}$ & $\begin{array}{l}398 \\
315\end{array}$ & $\begin{array}{l}1,852 \\
1,914\end{array}$ & $17 \underset{N D A}{ \pm} 42 \%$ & $\begin{array}{l}193 \\
\text { NDA }\end{array}$ & 6 & 65 & 0.01 & 1.8 \\
\hline $\begin{array}{l}21 \\
22\end{array}$ & $\begin{array}{l}1.13 E 6 \\
8.82 E 5\end{array}$ & $\begin{array}{l}1.67 E 5 \\
1.36 E 5\end{array}$ & $\begin{array}{l}7 \\
7\end{array}$ & $\begin{array}{l}1.17 E 4 \\
1.33 E 4\end{array}$ & $\begin{array}{l}1.33 E 5 \\
1.51 E 5\end{array}$ & 6 & 65 & 0.01 & 0.2 \\
\hline $\begin{array}{l}23 \\
24\end{array}$ & $\begin{array}{l}6.26 E 5 \\
6.35 E 5\end{array}$ & $\begin{array}{l}285 \\
317\end{array}$ & $\begin{array}{l}2,196 \\
2,883\end{array}$ & $\begin{array}{l}\text { NDA } \\
\text { NDA }\end{array}$ & $\begin{array}{l}\text { NDA } \\
\text { NDA }\end{array}$ & 6 & 65 & 0.02 & 0.5 \\
\hline $\begin{array}{l}25 \\
26\end{array}$ & $\begin{array}{l}6.95 E 5 \\
6.17 E 5\end{array}$ & $\begin{array}{l}4.35 E 4 \\
5.63 E 4\end{array}$ & $\begin{array}{l}16 \\
11\end{array}$ & $\begin{array}{l}5.56 E 3 \\
1.22 E 4\end{array}$ & $\begin{array}{l}6.31 E 4 \\
1.39 E 5\end{array}$ & 6 & 65 & 0.695 & 0.5 \\
\hline $\begin{array}{l}27 \\
28\end{array}$ & $\begin{array}{l}5.88 E 5 \\
6.15 E 5\end{array}$ & $\begin{array}{l}389 \\
489\end{array}$ & $\begin{array}{l}1,512 \\
1,258\end{array}$ & $34 \pm \underset{\text { NDA }}{39 \%}$ & $\begin{array}{l}386 \\
\text { WDA }\end{array}$ & 3 & 65 & 0.01 & 0.5 \\
\hline $\begin{array}{l}29 \\
36\end{array}$ & $\begin{array}{l}7.37 E 5 \\
6.19 E 5\end{array}$ & $\begin{array}{r}3.05 E 3 \\
244\end{array}$ & $\begin{array}{r}2.42 \\
2.537\end{array}$ & $\begin{array}{l}\text { NDA } \\
\text { NDA }\end{array}$ & $\begin{array}{l}\text { NOA } \\
\text { NDA }\end{array}$ & 12 & 65 & 0.01 & 0.5 \\
\hline $\begin{array}{l}31 \\
32\end{array}$ & $\begin{array}{l}8.04 E 5 \\
5.93 E 5\end{array}$ & $\begin{array}{l}437 \\
486\end{array}$ & $\begin{array}{l}1,840 \\
1,220\end{array}$ & $\begin{array}{r}11 \pm \underset{\mathrm{NDA}}{61 \%} \\
\text { r }\end{array}$ & $\begin{array}{l}125 \\
\mathrm{MDA}\end{array}$ & 3 & 65 & 0.02 & 0.5 \\
\hline $\begin{array}{l}33 \\
34\end{array}$ & $\begin{array}{l}6.61 E 5 \\
6.29 E 55\end{array}$ & $\begin{array}{l}784 \\
673\end{array}$ & $\begin{array}{l}939 \\
935\end{array}$ & $\begin{array}{l}\text { NDA } \\
\text { NDA }\end{array}$ & $\begin{array}{l}\text { NDA } \\
\text { NDA }\end{array}$ & 12 & 65 & 0.122 & 0.5 \\
\hline 35 & $8.76 E 5$ & $1.44 E 5$ & 6 & $4.56 E 3$ & $5.18 E 4$ & 6 & 65 & $\theta$ & 0.5 \\
\hline
\end{tabular}

(a) Treatment of a coupog $\left(8.8 \mathrm{~cm}^{2}\right)$ with $120 \mathrm{~mL}$ of $\mathrm{Ce}(\mathrm{IV})$ and $\mathrm{HNO}_{3}$.

(b) Surface ares, $8.8 \mathrm{~cm}^{2}$

(c) Meets waste acceptance specifications if $<2,290 \mathrm{dpm}$ garma $/ 190 \mathrm{~cm}^{2}$ surface.

(d) NDA = Be low detection 1 imit. 


\section{IABLE A.3. Decontamination Observations}

\begin{tabular}{|c|c|c|c|c|c|c|}
\hline \multirow[b]{2}{*}{ Coupon. } & \multicolumn{2}{|c|}{ Observations after Decontamination } & \multirow{3}{*}{$\begin{array}{c}\text { Contact } \\
\text { Iime h } \\
\begin{array}{c}6 \\
6\end{array}\end{array}$} & \multirow{3}{*}{$\begin{array}{c}\text { Tempera- } \\
\text { ture. }{ }^{\circ} \mathrm{C} \\
25 \\
25\end{array}$} & \multirow{3}{*}{$\begin{array}{c}C e(I V) \text { H } \\
0.01 \\
0.01\end{array}$} & \multirow{3}{*}{$\begin{array}{c}\mathrm{HNG}_{3} \mathrm{M} \\
0.5 \\
0.5\end{array}$} \\
\hline & Solution & Coupon Surface & & & & \\
\hline $\begin{array}{l}11 \\
12\end{array}$ & $\begin{array}{l}\text { Clear, yellow-orange } \\
\text { Clear, yellow-arange }\end{array}$ & $\begin{array}{l}\text { Oxide layer not renoved } \\
\text { Oxide layer not renoved }\end{array}$ & & & & \\
\hline $\begin{array}{l}13 \\
14\end{array}$ & $\begin{array}{l}\text { Clear, orange } \\
\text { Clear, orange }\end{array}$ & $\begin{array}{l}\text { Oxide layer removed } \\
\text { Oxide layer partially removed }\end{array}$ & 6 & 45 & 0.01 & 0.5 \\
\hline $\begin{array}{l}15 \\
16\end{array}$ & $\begin{array}{l}\text { Clear, yel low-orange } \\
\text { Clear, yel low-orange }\end{array}$ & $\begin{array}{l}\text { Clean, no oxide } \\
\text { Clean, no oxide }\end{array}$ & $\begin{array}{l}6 \\
6\end{array}$ & $\begin{array}{l}65 \\
65\end{array}$ & 0.01 & $\begin{array}{l}0.5 \\
0.5\end{array}$ \\
\hline $\begin{array}{l}17 \\
18\end{array}$ & $\begin{array}{l}\text { Very cloudy, yellow } \\
\text { Very cloudy, yellow }\end{array}$ & $\begin{array}{l}\text { Clean, no oxide } \\
\text { Clean, patches of oxide }\end{array}$ & 6 & 90 & 0.01 & 0.5 \\
\hline $\begin{array}{l}19 \\
20\end{array}$ & $\begin{array}{l}\text { Clear, yellow-orange } \\
\text { Clear, yel low-orange }\end{array}$ & $\begin{array}{l}\text { Clean, no oxide } \\
\text { Clean, no oxide }\end{array}$ & $\begin{array}{l}6 \\
6\end{array}$ & $\begin{array}{l}65 \\
65\end{array}$ & $\begin{array}{l}0.01 \\
0.01\end{array}$ & $\begin{array}{l}1.0 \\
1.0\end{array}$ \\
\hline $\begin{array}{l}21 \\
22\end{array}$ & $\begin{array}{l}\text { Cloudy, yellow } \\
\text { Cloudy, yellow }\end{array}$ & $\begin{array}{l}\text { Oxide layer not removed } \\
\text { Oxide layer not removed }\end{array}$ & $\begin{array}{l}6 \\
6\end{array}$ & $\begin{array}{l}65 \\
65\end{array}$ & $\begin{array}{l}0.01 \\
9.01\end{array}$ & $\begin{array}{l}0.2 \\
0.2\end{array}$ \\
\hline $\begin{array}{l}23 \\
24\end{array}$ & $\begin{array}{l}\text { Cloudy, orange } \\
\text { Clear, orange }\end{array}$ & $\begin{array}{l}\text { 59\%, covered with oxide } \\
\text { Clean, no oxide }\end{array}$ & 6 & 65 & 0.62 & D. 5 \\
\hline $\begin{array}{l}25 \\
26\end{array}$ & $\begin{array}{l}\text { Clear, yellow-orange } \\
\text { Clear, yellow-orange }\end{array}$ & $\begin{array}{l}\text { Oxide layer not removed } \\
\text { Oxide layer not removed }\end{array}$ & $\begin{array}{l}6 \\
6\end{array}$ & $\begin{array}{l}65 \\
65\end{array}$ & $\begin{array}{l}0.005 \\
0.095\end{array}$ & $\begin{array}{l}0.5 \\
0.5\end{array}$ \\
\hline $\begin{array}{l}27 \\
28\end{array}$ & $\begin{array}{l}\text { Slight ly cloudy } \\
\text { Slight ly cloudy }\end{array}$ & $\begin{array}{l}\text { Clean, no oxide } \\
\text { Clean, no oxide }\end{array}$ & $\begin{array}{l}3 \\
3\end{array}$ & $\begin{array}{l}65 \\
65\end{array}$ & $\begin{array}{l}0.01 \\
0.01\end{array}$ & $\begin{array}{l}0.5 \\
0.5\end{array}$ \\
\hline $\begin{array}{l}29 \\
30\end{array}$ & $\begin{array}{l}\text { Clear, yellow } \\
\text { Clear, yellow }\end{array}$ & $\begin{array}{l}\text { Clean, no oxide } \\
\text { Clean, no oxide }\end{array}$ & $\begin{array}{l}12 \\
12\end{array}$ & $\begin{array}{l}65 \\
65\end{array}$ & $\begin{array}{l}0.01 \\
0.01\end{array}$ & $\begin{array}{l}0.5 \\
0.5\end{array}$ \\
\hline $\begin{array}{l}31 \\
32\end{array}$ & $\begin{array}{l}\text { Very cloudy, orange } \\
\text { Very cloudy, orange }\end{array}$ & $\begin{array}{l}\text { Very clean, no oxide } \\
\text { Very clean, no oxide }\end{array}$ & $\begin{array}{l}3 \\
3\end{array}$ & $\begin{array}{l}65 \\
65\end{array}$ & $\begin{array}{l}0.02 \\
0.02\end{array}$ & $\begin{array}{l}0.5 \\
0.5\end{array}$ \\
\hline $\begin{array}{l}33 \\
34\end{array}$ & $\begin{array}{l}\text { Cloudy, yellow } \\
\text { Cloudy, yellow }\end{array}$ & $\begin{array}{l}\text { Oxide on } 25 \% \text { of surface } \\
\text { Oxide on } \sim 20 \% \text { of surface }\end{array}$ & 12 & 65 & 0.82 & 0.5 \\
\hline 35 & Clear, yellow-orange & Oxide layer not removed & 6 & 65 & $\theta$ & 0.5 \\
\hline
\end{tabular}




\section{DISTRIBUTION}

No. of

Copies

\section{OFFSITE}

12 DOE/Office of Scientific and Technical Information

2 DOE Office of Civilian Radioactive Waste Management

Forrestal Building

Washington, DC 20585

ATTN: J. W. Bartlett, RW-1

S. Brocum, RW-22

13 D. B. Leclaire, DP-30

DOE Office of Defense Programs GTN

Washington, DC 20545

ATTN: K. A. Chacey, EM-30

J. A. Coleman, EM-35

C. R. Cooley, EM-.55

S. Cowan, EM-30

J. J. Fiore, EM-423

C. Frank, EM-50

M. Frei, EM-34

T. S. Gutman

J. E. Lytle, EM-30

T. W. McIntosh, EM-343

V. G. Trice, EM-343

H. F. Walter, EM-343

J. 0. Bunting

Division of High-Level Waste Nuclear Regulatory Commission Washington, DC 20555

J. M. Taylor

Office for the Executive

Director for Operations

Mail Station 17-HI

Nuclear Regulatory Commission

Washington, DC 20555
No. of

Copies

W. F. Holcomb

Environmental Protection Agency

Office of Radiation Programs (ANR-460)

401 M Street S.W.

Washington, DC 20460

P. A. Saxman

DOE Albuquerque Operations Office

P.0. Box 5400

Albuquerque, NM 87185

3 DOE Idaho Operations Office 785 DOE Place

Idaho Falls, ID 83402

ATTN: C. R. Enos

M. W. Shupe

J. E. Solecki

M. R. Jugan

DOE Oak Ridge Operations

Office

P.O. BoX E

Oak Ridge, TN 37830

F. T. Fong

DOE San Francisco Operations 1333 Broadway

Oakland, CA 94612

H. Brandt

DOE Savannah River Operations Office

P. 0. Box A

Aiken, SC 29801 
No. of

Copies

W. S. Ketola

DOE West Valley Project

P.0. Box 191

West Valley, NY 14171

C. P. Gertz

DOE Yucca Mountain Project

Phase 2

Suite 200

101 Convention Center Drive

Las Vegas, NV 89109

3 Oak Ridge National Laboratory

P.0. Box $Y$

Oak Ridge, TN 37830

ATTN: S. A. Meacham

L. J. Mezga

T. H. Row

2 Sandia Laboratories

P.0. Box 5800

Albuquerque, NM 87185

ATTN: R. W. Lynch

Dept. 6300

Technical Library

Westinghouse Idaho

Nuclear Co., Inc.

P.0. Box 4000

Idaho Falls, ID 83401

ATTN: D. Knecht

4 Westinghouse Savannah River Co.

Savannah River Site

Aiken, SC 29801

ATTN: J. A. Gentilucci

E. W. Holtzscheiter

C. T. Randall

W. N. Rankin
No. of

Copies

4 West Valley Nuclear

Services Co.

P.0. Box 191

West Valley, NY 14171

ATTN: S. M. Barnes

D. Burnes

R. Paimer

L. L. Petkus

S. G. Harbison

New York State Energy Research

\& Development Authority

P.0. Box 191

West Valley, NY 14171

I. L. White

New York State Energy Research \& Development Authority

P.0. Box 191

Empire State Plaza

Albany, NY 12223

\section{ONSITE}

4 DOE Richland Field office

R. W. Brown, A5-10

S. T. Burnum, A5-16

P. E. Lamont, A5-16

E. C. Norman, A5-16

7 Westinghouse Hanford Company

K. R. Shah, G6-02

P. S. Schaus, A4-90

R. A. Smith, G6-02

G. E. Stegan, G6-06

L. D. Swenson, G6-06

E. T. Weber, G6-08

R. N. Wagner, G6-08 
No. of

Copies

52 Pacific Northwest Laboratory

C. R. Allen, P7-43

L.M.G. Ballou, P7-18

L. A. Bray, P7-25 (20)

W. F. Bonner, P7-41

G. H. Bryan, P7-25

H. C. Burkholder, P7-41

J. M. Creer, G6-01

M. R. Eimore, P7-19 (10)

G. A. Jensen, G6-01

D. E. Larson, G6-01

J. L. MCE1roy, P7-46

J. M. Perez, Jr., P7-41

R. K. Quinn, K2-50

P. A. Scott, PT-19

L. J. Sealock, Jr., K2-10

G. J. Sevigny, P7-43

R. E. Westerman, P8-44

E. J. Wheelwright, P7-25

Publishing Coordination

Technical Report Files (5) 

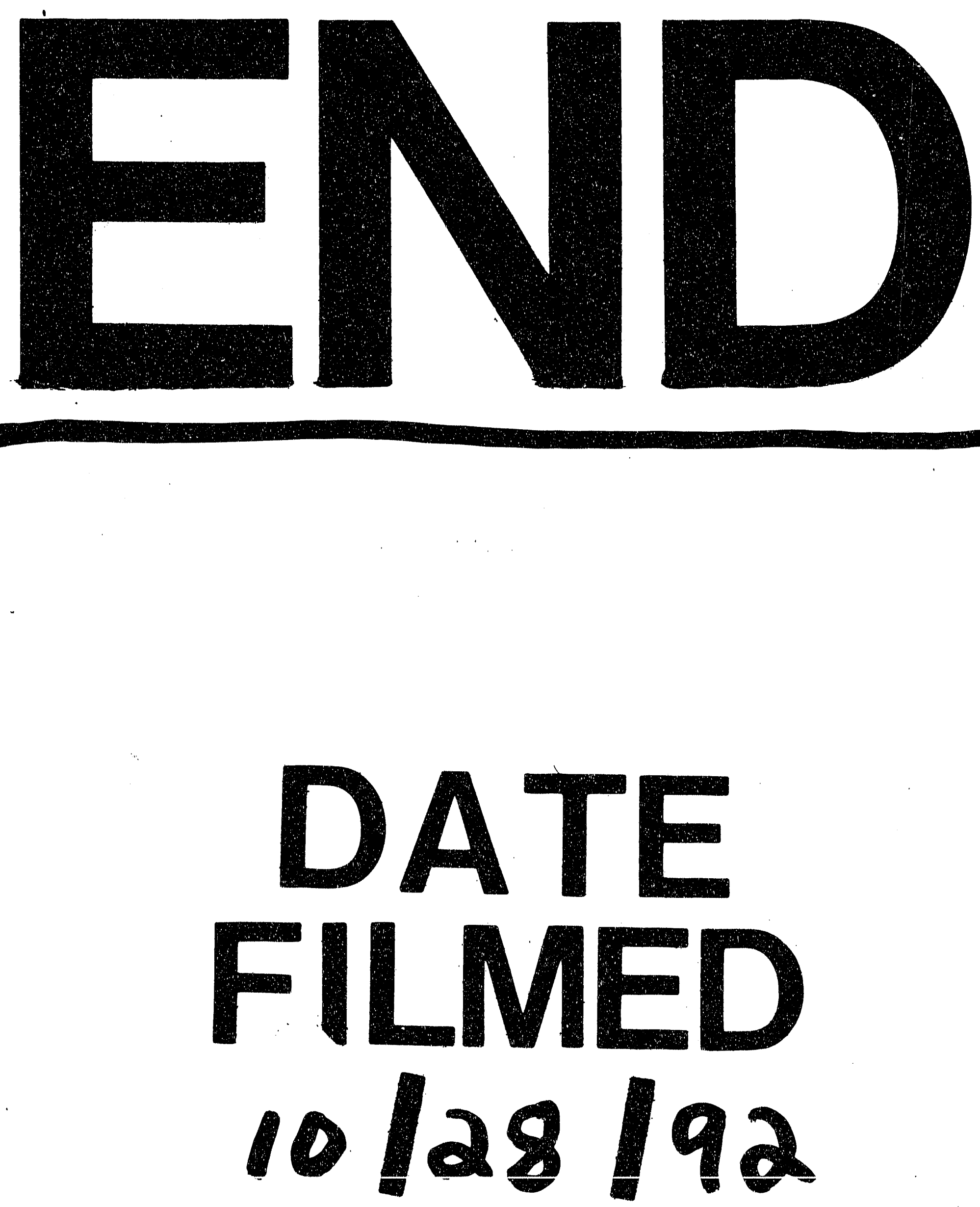
